MATEC Web of Conferences 9, 05004 (2013)

DOI: $10.1051 /$ matecconf/20130905004

(C) Owned by the authors, published by EDP Sciences, 2013

\title{
Study on prevention of spread of vertical fire along finishing materials for external wall of high-rise buildings
}

\author{
Yong Ho Yoo ${ }^{1}$, Seung Un Chae ${ }^{1}$, Heung Youl Kim ${ }^{1}$ and Woon Hyung Kim² \\ ${ }^{1}$ Korea Institute of Construction Technology \\ 2 Kyungmin University, Korea
}

\begin{abstract}
Although there are laws in the Korea Building Act relating to exterior finishing materials, fireproof structures and fire-stop of curtain wall structures, the standards relating to and test methods on securing detailed fire safety functions for exterior materials of all buildings including high-rise buildings have not been prepared. This is due to the fact that test methods and standards to quantitatively evaluate the vertical fire spread of the exterior material of buildings do not exist.

In addition, while semi non-combustible materials or non-combustible materials are required to be used to prevent fire spread in buildings which exceed 30-stories, it is necessary to review the standards and regulations in cases where fire blocking systems, capable of preventing the vertical fire spread within the curtain wall, are installed to consider permitting the utilization of fire retardant material following an assessment of the construction characteristics of high-rise buildings.

The functional evaluation standards and test methods on the vertical fire spread introduced in this study will be a more effective method for performing evaluations to prevent fire spread compared to the currently utilized method of performing small scale tests.
\end{abstract}

\section{INTRODUCTION}

Following the development of construction technology in Korea, the construction of high rise buildings has increased due to their various benefits from the social and economic perspective, including the enhancement of a city's image through the creation of landmarks and the effective utilization of vertical space. However, the potential for fire-related accidents and the resulting threat to human life and financial losses mean that high rise buildings carry a high level of potential risk. As can be seen from the fires that occurred in Knowsley Heights Apartment in Liverpool, England in 1991 and the Woosin Golden Sweet in Haewundae, Korea in 2010, fire can cause large scale damage if it starts from the inside of the building and grows to a flashover that spreads through windows in a rapid and vertical manner along exterior materials constructed in the building. According to fire-related statistics from the National Emergency Management Agency, exterior wall fire events in buildings in Korea numbered 1,681 in 2009, which accounted for approximately $3.6 \%$ of all fire events. In light of this issue being one with social importance, this study will analyze the relevant legal standards through case studies and introduce relevant research trends in order to propose the technical developments that are capable of preventing vertical fire spread in exterior materials.

\section{CASE ANALYSIS ON FIRE}

The fire in the Woosin Golden Sweet Officetel Building in Haewundae, Busan, which occurred last year was a 38-storey high rise building with a complex panel curtain wall structure. General information on the on the fire is provided below.

This is an Open Access article distributed under the terms of the Creative Commons Attribution License 2.0, which permits unrestricted use, distribution, and reproduction in any medium, provided the original work is properly cited. 


\section{MATEC Web of Conferences}

Table 1. Statistic data for exterior wall fire in each usage of the building.

\begin{tabular}{|c|c|c|c|c|}
\hline \multirow{2}{*}{ Classification } & Usage & \multicolumn{3}{|c|}{ Number of fire } \\
\cline { 2 - 5 } & $\mathbf{2 0 0 7}$ & $\mathbf{2 0 0 8}$ & $\mathbf{2 0 0 9}$ \\
\hline \hline \multirow{3}{*}{ Residential District } & Single House & 262 & 320 & 423 \\
\cline { 2 - 5 } & Apartment House & 73 & 92 & 313 \\
\cline { 2 - 5 } & Other houses & 13 & 28 & 85 \\
\hline \multirow{4}{*}{$\begin{array}{c}\text { Education facility } \\
\text { District }\end{array}$} & 31 & 37 & 27 \\
\cline { 2 - 5 } & Store & 224 & 226 & 221 \\
\cline { 2 - 5 } & Assembly facility & 39 & 35 & 31 \\
\cline { 2 - 5 } & Medical welfare & 28 & 40 & 29 \\
\cline { 2 - 5 } & Industrial facility & 302 & 322 & 290 \\
\cline { 2 - 5 } & $\begin{array}{c}\text { Transportation and } \\
\text { vehicle facility }\end{array}$ & 17 & 24 & 18 \\
\cline { 2 - 5 } & Cultural assets facility & 1 & 1 & 0 \\
\cline { 2 - 5 } & Living service & 467 & 584 & 499 \\
\cline { 2 - 5 } & Other service facility & 171 & 183 & 141 \\
\hline
\end{tabular}

\subsection{General on fire}

A. Name: Woosin Golden Sweet (skyscraper apartment complex) located in Marine City, Haewundae-gu, Busan

B. Structure: 4 underground levels and 38 levels above ground (underground levels $2 \sim 4$ is for parking lot, and 1 underground floor is for the mechanical room, aboveground levels $1 \sim 3$ is for neighborhood living facility, 4 levels for the pit floor and levels $5 \sim 38$ is for the office facility (officetel)

Exterior wall: a curtain wall structure of aluminum composite panels. The structure is composed of general aluminum panels $(4 \mathrm{~mm})$ and glass wool $(50 \mathrm{~mm})$ that have been combined as one structure in the angle (channel) and fixed to the concrete slab or wall.

C. Date: 1st of October, 2010 (Friday) at 11:33 18:50 (for 7 hours)

D. Damages: 4 wounded (3 residents and 1 fire fighter) and 5 billion won of damage to property

E. Cause of fire: assumed to have started in the room for cleaners on the 4th floor and spread to the 37th floor following the polyethylene foam (combustible materials), which was an internal filler of aluminum composite panel, glass wool and composite panel adhesive agent (combustible material) catching fire. (overall analysis of data in fire station and relevant interviews).

\subsection{Analysis of relevant legal requirements}

An analysis of the We performed a review of the relevant laws and regulations in place at the time of the accident to identify the problems.

A. Review of exterior wall regulation within fireproof district

Fire resistance structure: Building Act Item $\square$, Article 51

- Building Act, Article 51, Item $\square$ : major structure and exterior wall shall be composed of fireproof structure within fireproof district. 

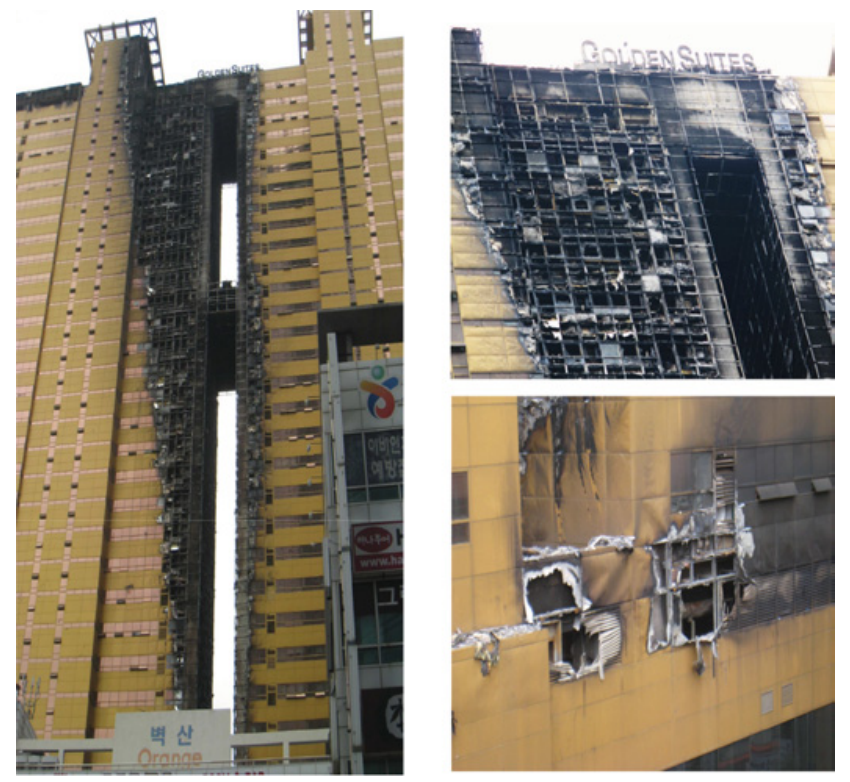

Figure 1. Fire in Woosin Golden Sweet of Haewundae.

- The high rise apartment complex of in Haewundae was constructed in 1992 and the exterior fireproof structure was required to be fire resistant for 30 minutes at that time.

Also, the high rise building in Haewundae where the fire took place was a fireproof structure in accordance with the Act, as the aluminum composite panel curtain wall was additionally attached to the exterior wall concrete (fireproof structure, evacuation regulation, Article 3).

$\square$ Fire retardant function: in regards to the fire retardant function of the exterior wall materials, the Enforcement Decree of Building Act to use the material of fire retardant function was awaiting implementation and as of 2010 there was no relevant regulation.

B. Exterior wall regulation out of fireproof district

$\square$ Fireproof structure: there is no regulation on the fireproof structures for exterior wall out of fireproof district

$\square$ Fire retardant function: in regards to fire retardant function of exterior wall materials, the Enforcement Decree of Building Act to use the material of fire retardant function was awaiting implementation and as of 2010 there was no relevant regulation.

C. Results on the analysis of legal requirements

In the case of the high rise apartment complex in Haewundae, it had been constructed in the fireproof district in 1992, and as it was the fireproof structure of concrete, it had no legal issues, and regardless of the additional attachment to the aluminum composite panel curtain wall structure it has been evaluated that there was no violation of law at the time of the fire in regards to the exterior wall finishing material.

In other words, the relevant regulations on exterior wall finishing materials, fireproof structures and fireproof fillers of curtain wall structures were regulated as follows in accordance with the Building Act in Korea but detailed protection standards, test methods etc. for vertical fire spreads are not provided. 


\section{MATEC Web of Conferences}

Exterior Finishes

- Building Act Article 52 - Finishing Materials for Buildings

Exterior Fireproof Structures

- Building Act Article 51 - Buildings in Fire Prevention Zones

- Regulation of the Standards of Egress and Fire Protection Construction in Buildings Article 3-Fireproof Structures

Fireproof filler for Exterior Curtain Wall Structures

- Building Act Article 51 - Buildings in Fire Prevention Zones,

- Regulation Article 3 of the Standards of Egress and Fire Protection Construction in Buildings Article 3-Fireproof Structures.

It is recommended that detailed regulation should be enacted such as Enforcement Decree etc. for the use of materials (non-combustible, semi noncombustible materials, fire retardant materials etc.) as well as test methods in the target district (commercial district etc.) for fire protection function of finishing materials based on the Building Act, Article 52 which shows only legal background because there is no detailed standards and test methods for vertical fire spread of the exterior materials of building.

\section{TECHNOLOGY DEVELOPMENT TO PREVENT VERTICAL FIRE SPREAD FOR EXTERIOR MATERIALS OF BUILDINGS}

There are no detailed standards, test methods etc. to secure the fire protection function for exterior finishing materials of all buildings, including high rise buildings in accordance with current regulations in Korea. Hence, it is necessary to prepare detailed contents for target districts (commercial district etc.) and fire protection regulations for evacuation in the Enforcement Decree of Building Act as soon as possible and also study test methods and its standards for quantitative evaluation of the vertical fire spread.

To do regard, the Korea Institute of Construction Technology is carrying out research on and the development of technology to prevent the vertical fire spread of exterior materials of buildings (jointly conducted with researcher of Living Environment Test of Construction in Korea and Kyungwon University) and the study is ongoing to assess the vertical fire spread evaluation and develop the prevention technology, applying more effective and practical mockup performance test methods ( $4 \mathrm{~m}$ specimens) beyond the current test methods, which utilizes small scales (less than $10 \mathrm{~cm}$ specimens) [2].

\subsection{Mockup test for vertical fire spread}

Although social issues and concerns have been raised about exterior wall fires and fires on sandwich panel of high rise buildings etc., research on this issue has been short. In particular, research studies and mockup tests to provide legal standards for exterior materials have not been carried out, which has led to it being recognized as an obstacle. Hence, as fire spread tests on urethane foam using mockup facilities for the fire test as well as mockup tests for fire spread characteristics of exterior walls are performed, experimental data can be secured to prevent fire spread of exterior materials as well as basic data to develop standard test sizes and test equipment.

A. Fire mockup experiment on urethane foam

The test was performed using a mockup calorimeter with $10 \mathrm{MW}$. Also, the heat release rate and poisonous gas was measured with an Oxygen Consumption Calorimeter [3] by using $10 \mathrm{~m}$ diameter smoke collection hood as shown in the Figure 2.

The urethane foam, which is known to be susceptible to fires, was constructed based on those found in actual fire sites, and cotton with $100 \mathrm{ml}$ Heptane was used in the low and right side 


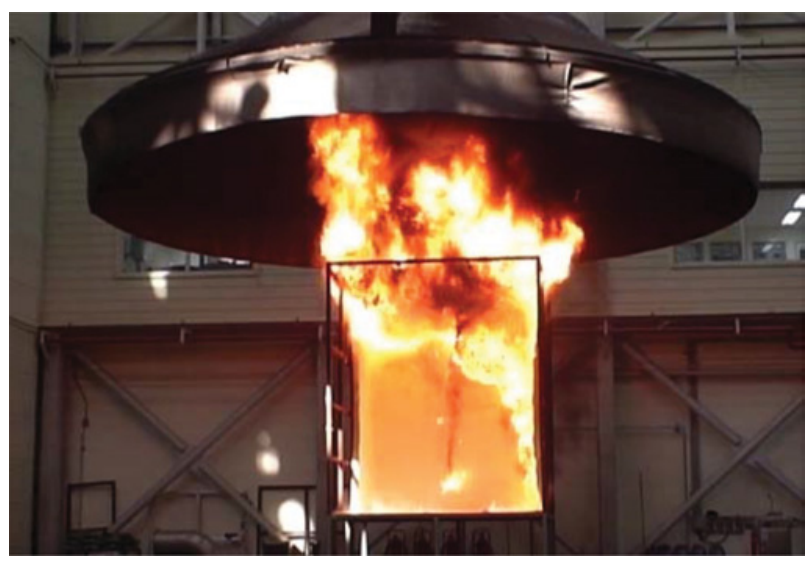

Figure 2. Fire mockup test of Urethane foam.z

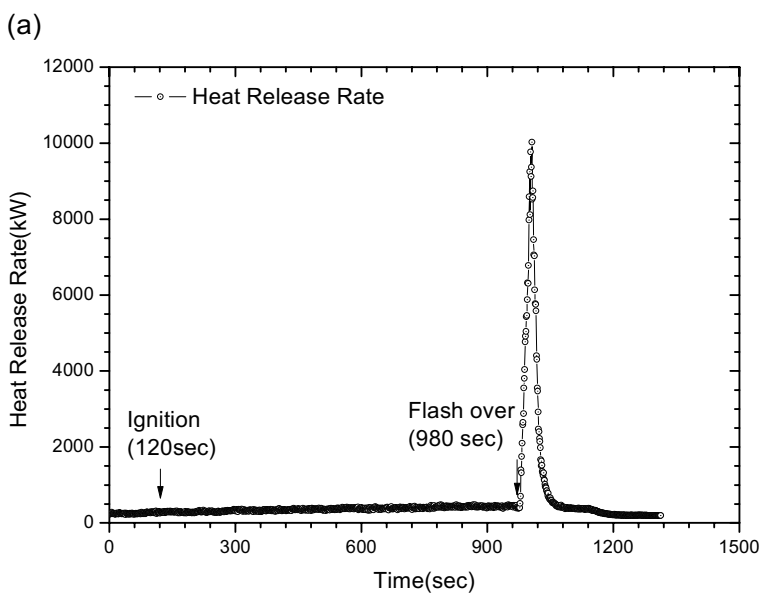

Figure 3-a. Result on mockup test of Urethane foam (HRR,).

of the corner as an initial source of the ignition. The result of the test is shown in Figure 3. The flame of the urethane foam started to spread 12 minutes following the initial ignition, and was advanced enough to be a flashover at 14 minutes. The maximum heat release was recorded 15 minutes following the initial ignition, reaching $10 \mathrm{MW}$, and the maximum level of the poisonous gas carbon monoxide was measured after 15 minutes as well, recording $1044 \mathrm{ppm}$.

The test shows that in the case of urethane foam, which is frequently used as a core material for buildings, the flame spread extremely rapidly and became a flashover very quickly.

B. Trial vertical spread experiment of exterior material

Before developing the standard test method and evaluation equipment to evaluate the vertical fire spread of exterior material of building, pre-experiments using the same materials as in actual fire accidents that took place in 2008 was performed. The fire was reconstructed by applying the exterior source of ignition (it is believed that the fire was caused by cigarette butts) in the bottom of the building and placing exterior material in the same experiment facility as mentioned above Figure 4. Figures 4 and 5 show the test and the measurement result of the heat release rate, respectively. 
MATEC Web of Conferences

(b)

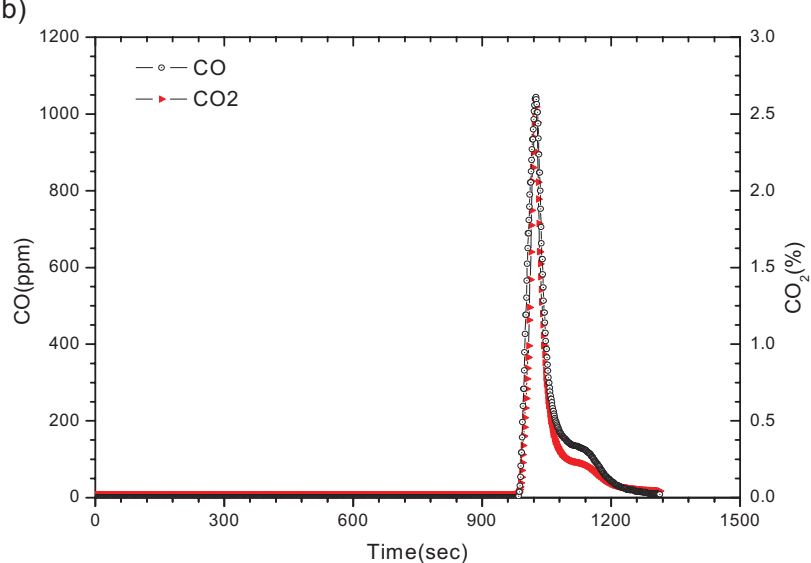

Figure 3-b. Result on mockup test of Urethane foam $\left(\mathrm{CO}, \mathrm{CO}_{2}\right)$.

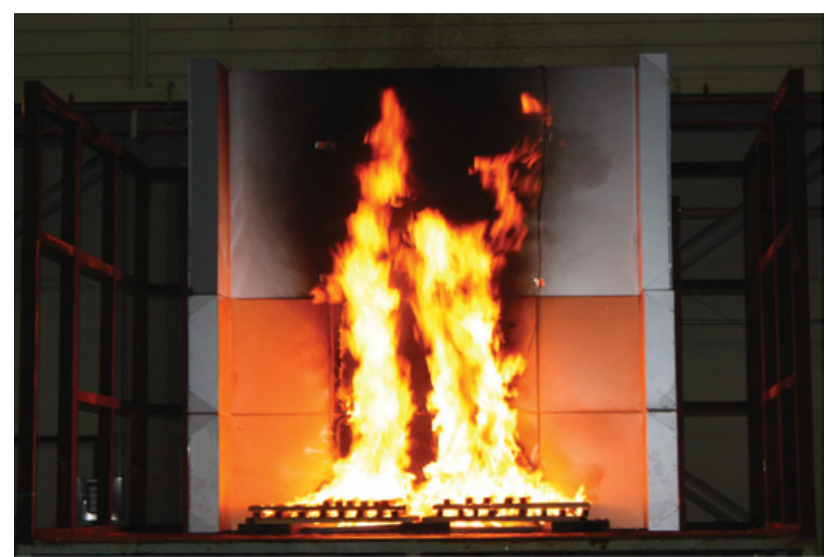

Figure 4. Vertical spread test of exterior material.

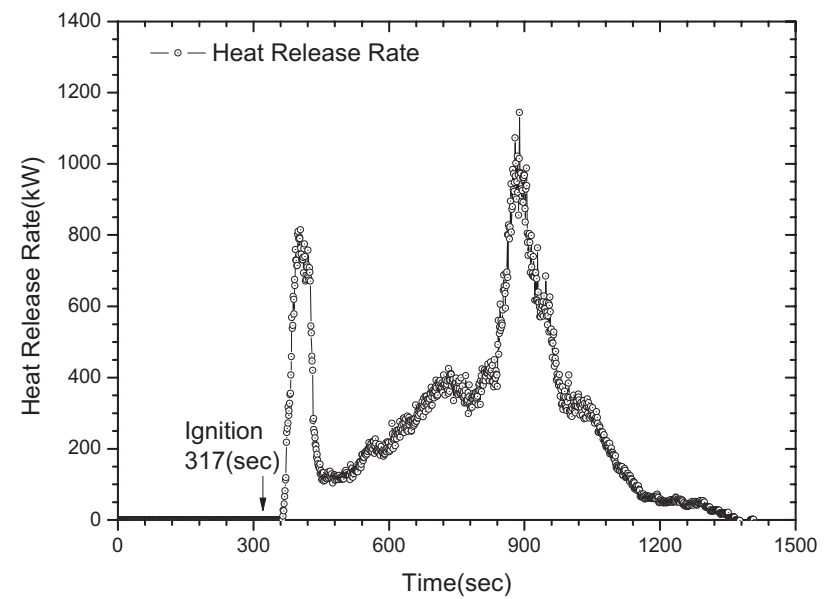

Figure 5. Trial experiment result on vertical spread of exterior material (HRR). 


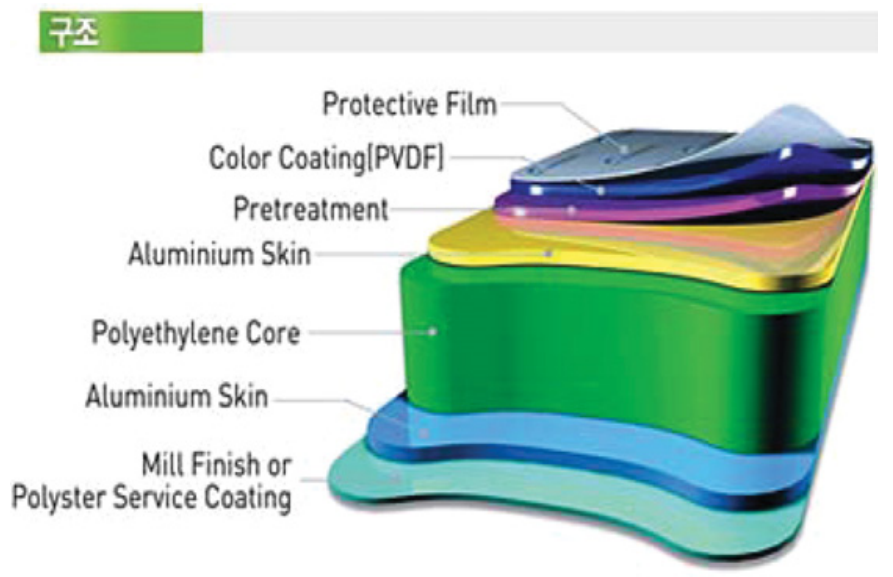

Figure 6. Compound panel structure of aluminum.

The fire was rapidly developed by burning a groove in the external material as soon as it was ignited, and the spread of the flame slowed during the 3 to 4-minute time period when the flame was transmitted into the interior of the exterior material with the melting of the interior material. Following the slow spread, the flame was transmitted to the adjacent material and proceeded to the second phase of its development. The maximum heat release materialized after the second flashover, and the level is estimated to be $11 \mathrm{MW}$ as shown in Figure 5.

It has been confirmed by the experiment that in the case of the general Styrofoam that is used as material for buildings for the enhancement of insulation of the exterior material, the vertical fire was able to spread rapidly after it was ignited.

\subsection{Development of standard function test method and equipment}

As we confirmed from the two experiments as shown above, national and international standards (BS 476 Part 33, NFPA 101 Life Safety Code etc.) and test methods have been analyzed to evaluate the vertical fire spread function using a mockup for the exterior material of buildings. As a result, it has been assessed that the most suitable test method is the ISO 13785-2 "Reaction-to-Fire tests for facadesPart 2 Large-scale test" [4] to simulate and evaluate the phenomena showing ignition, firing inside of the space, flashover, the flame transmitted to the exterior and then vertical fire spread. ISO 13785-2 includes the test specimen with 5.7 height and combustion room for $20 \sim 100 \mathrm{~m}^{3}$ size. It has the advantage to make the same flame as the fire of actual buildings blown out of the window by installing the gas burner system in the interior of the combustion room and loading 16 wood cribs. It is expected to be the effective prevention function method of the vertical fire spread that the vertical fire spread for the actual exterior structure system (including window) of aluminum composite panel, glass wool etc. (over $3 \mathrm{~m}$ actual thickness and specimen height) can be evaluated beyond limitation to evaluate only the fire retardant function of the single material (size of specimen: $10 \mathrm{~cm}(\mathrm{~W}) \times 10 \mathrm{~cm}(\mathrm{~L}) \times 5 \mathrm{~cm}(\mathrm{H})$ ).

\subsection{Mockup fire test applying ISO 13785-2}

In the study, the mockup fire test is performed by applying the international fire test standard ISO 137852(2002) "Reaction-to-fire tests for facades-Part 2: Large-scale test", to evaluate the vertical fire spread function of exterior finishing materials of buildings and to apply to the future vertical spread function standard. For the mockup test, the aluminum composite panel that was used in the building complex in Haewundae, Busan, was selected to be used as an exterior wall finishing material. Figure 6 shows 


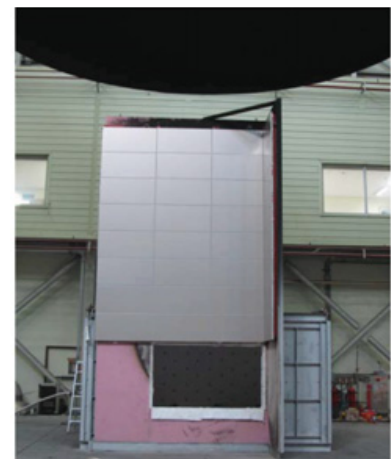

a. test start

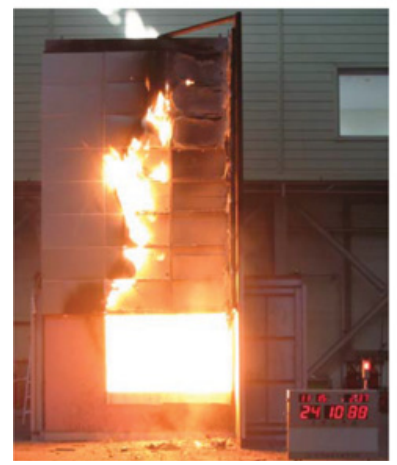

c. test time: 24 minute

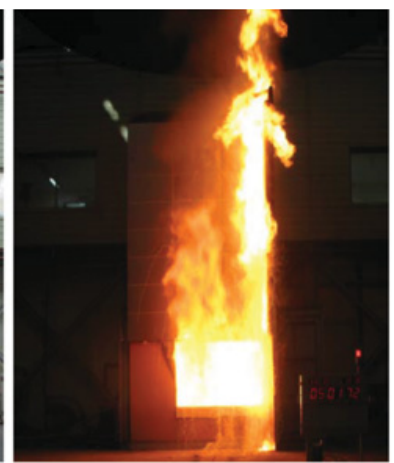

b. test time: 5 minute

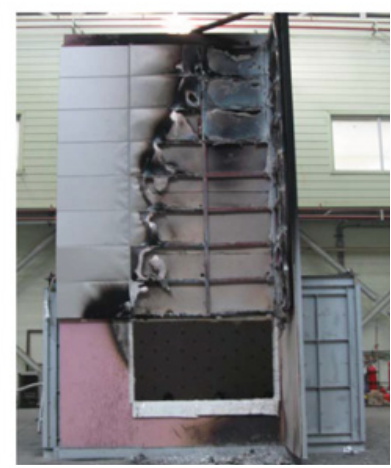

d. test end

Figure 7. Photo of real scale fire test.

the aluminum composite panel applied to the building complex in Haewundae, Busan and a composite material, which is composed of $0.5 \mathrm{~mm}$ aluminum, $3 \mathrm{~mm}$ polyethylene foam and $0.5 \mathrm{~mm}$ aluminum (Korea Fire-rating Building Material Association, 2011) was used. It is the structure of the aluminum composite panel curtain wall using the system which the structure composed of $50 \mathrm{~mm}$ glass wool in the composite panel is monolithically made to the angle and the monolithic structure is fixed to the concrete slab or the wall. The test equipment has been constructed in accordance with the ISO 13785-2 test method to test the mockup vertical fire spread for the general and aluminum composite panel and Figure 6 shows the structure.

To simulate the fire and to generate the exterior flame, the combustion room and the burner system within the combustion room was constructed. The air fan has been installed in the exterior of the combustion room to fulfill the following requirements: $+800^{\circ}$ average temperature and $(35 \pm 5) \mathrm{kW} / \mathrm{m}^{2}$ heat flow volume in 5 to 20 -minute sections for the exterior flame for the burner system. A total of 8 heat flow meters and 7 thermocouples were installed based on the test method in the frame of the specimen. The heat current system installed in the frame of the specimen was manufactured to be installed in parallel to the specimen wall to be identical surface of the heat flow meter with the finishing material when installing the exterior wall finishing material. The mockup vertical fire spread test was carried out for 25 minutes.

The temperature of the flame in the portal was measured during the test period of the fire as shown in Figure $8 \mathrm{a} \mathrm{T} 1 \sim \mathrm{T} 3$ and the temperature was $812 \sim 1021^{\circ}$ in the $2^{\text {nd }}$ stage of the current volume of propane gas to simulate flashover during the fire divided. The temperature variation is shown in $\mathrm{T} 4 \sim 7$ 


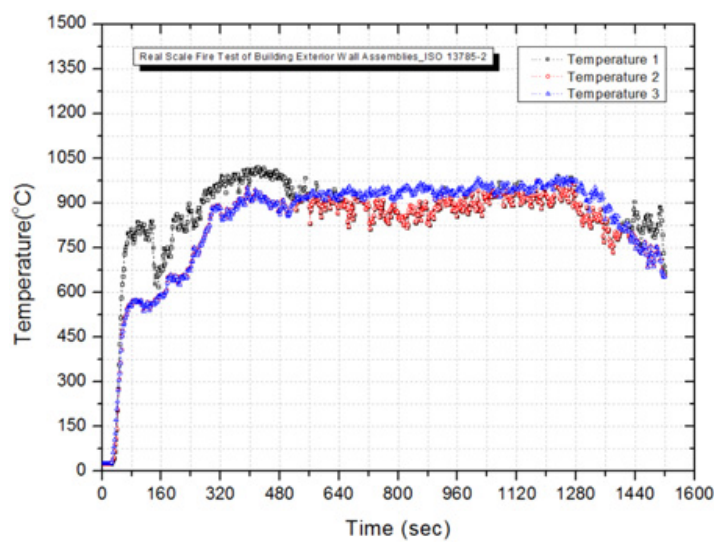

a. Temperature 1. Temperature 3(T1 T T3).

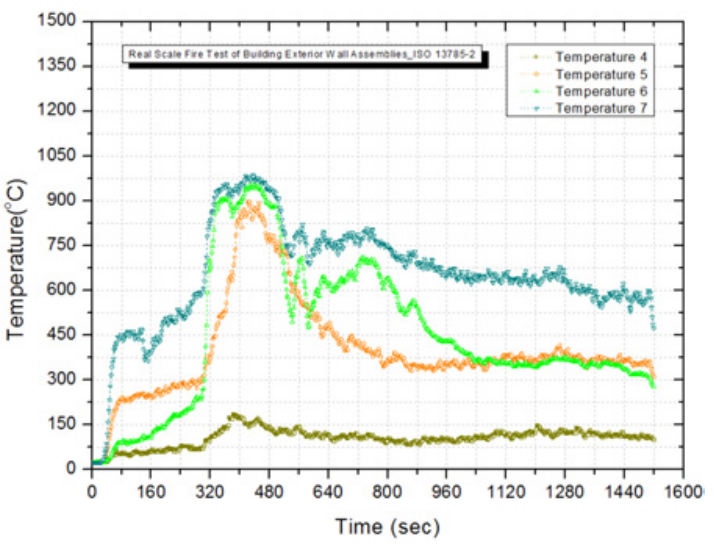

b. Temperature 4. Temperature 7(T4 T7).

Figure 8. Measured temperature by real scale fire test.

installed in the top of the specimen and T5 T7 have high temperature in the corner of the specimen as shown in Figure 8b. Low temperature variation is shown in $\mathrm{T} 4$ having relatively indirect transmission of the fire. As a result of the mockup fire test, for the vertical fire spread of the aluminum composite panel, the temperature has been rapidly increased in the initial stage of the test as well as in the $2^{\text {nd }}$ stage $(300 \mathrm{sec})$ showing maximum flame in the portal. It shows that there is high risk for the fire to be set due to the rapid and vertical fire spread when firing because no prevention effect of the fire spread exists for the flame. The time obtaining the maximum temperature is shown in T4 $\sim \mathrm{T} 7$ of Figure 8b. $987.7^{\circ}$ maximum temperatures has been measured in $\mathrm{T} 7$ and the time obtained is 436 seconds. The maximum temperature was obtained in approximately 7 minutes and 16 seconds in all of the points. As well as this, it shows that the vertical fire spread rapidly in 3 minutes after generating flashover in all points if 5 minutes is taken into account as the point generating maximum flame in the combustion room.

\section{ALTERNATIVE TO PREVENT VERTICAL FIRE SPREAD}

As described above, if there is fire on the exterior wall of the high-rise building, the flame rapidly spreads to the upper stories, and if a combustible coating agent (painting etc.) is used on the exterior finishing material, the fire spread is accelerated so that it should be prevented to reduce damages. Therefore, 2 methods are proposed as follows:

- If the coating for aesthetic is carried out on the exterior wall finishing material, non-combustible coating material is compulsory for the prevention of the fire spread.

- If a building is over 30 stories, semi noncombustible or non-combustible materials should be used to prevent the fire spread. However., fire retardant material is allowed if the fire blocking system is installed to prevent the vertical fire spread in the curtain wall in consideration of the construction characteristics (curtain wall) of the rise building.

The fire blocking system is the plate to block the fire installed in between stories to prevent rapid fire spread to the upper stories and explained in Table 2.

Recent exterior wall finishing material of buildings is composed of marble, stone, glass (curtain wall), red brick, architectural concrete etc. as a non-combustible material and aluminum composite panel (curtain wall) is used for the urban buildings considering various designs. In particular, the use of semi noncombustible material has increased. However, although additional costs could arise by 
Table 2. Case of the fire protection structure.

\begin{tabular}{|l|l|}
\hline Structure to prevent fire spread & Remark \\
\hline - Install the material in between each \\
story with over $1.2 \mathrm{~m}$ width and the \\
functions as described below ("S" in \\
the figure) \\
- Gypsum board with $12.5 \mathrm{~mm}$ \\
thickness and with the functions \\
- Dense mineral wool belt (over 100 K) \\
(over 50 mm thickness) \\
- Materials etc. with fireproof \\
performance for over 15 minutes
\end{tabular}

Table 3. Construction cost of panel per unit area (based on $50 \mathrm{~T}$ for wall).

\begin{tabular}{|l|c|l|l|l|l|}
\hline Classification & $\begin{array}{c}\text { Urethane sandwich } \\
\text { panel }\end{array}$ & \multicolumn{2}{|c|}{$\begin{array}{c}\text { Fire-resistant Styrofoam } \\
\text { sandwich panel }\end{array}$} & $\begin{array}{l}\text { Glass wool sandwich panel } \\
\text { (Density 48 K) }\end{array}$ \\
\hline $\begin{array}{l}\text { Unit price } \\
\left(\text { won/m }{ }^{2}\right)\end{array}$ & $\begin{array}{c}19,500 \sim \\
20,500\end{array}$ & $\begin{array}{l}21,000 \sim \\
24,000\end{array}$ & $\begin{array}{l}11,500 \sim \\
14,000\end{array}$ & $12,500 \sim 14,600$ & $16,700 \sim 17,500$ \\
\hline $\begin{array}{l}\text { Fire-resistant } \\
\text { level }\end{array}$ & $\begin{array}{l}\text { Fire- } \\
\text { resistant } \\
\text { material }\end{array}$ & $\begin{array}{l}\text { Semi fire- } \\
\text { resistant } \\
\text { material }\end{array}$ & $\begin{array}{l}\text { Fire-resistant } \\
\text { material }\end{array}$ & $\begin{array}{l}\text { Semi fire-resistant } \\
\text { material }\end{array}$ & Semi fire-resistant material \\
\hline
\end{tabular}

regulating the use of semi noncombustible material as the exterior wall finishing material, the cost is low as shown in Table 3. Therefore, it is evaluated that the vertical fire spread prevention and the derivative effect of minimization of the resulting damages are much bigger than the associated costs.

\section{CONCLUSION AND DISCUSSION}

The study has reviewed the relevant legal restrictions method by analyzing fire accidents to prevent the vertical fire spread for the exterior material of buildings and for the review, discussed the development of the standards and equipment for the function evaluation of the mockup vertical fire spread.

- It is recommended that legal measures should be implemented to prevent the vertical fire spread by taking active actions such as the use of the materials with fire retardant properties for the exterior material of the buildings, the installation of structure preventing fire spread etc.

- It is necessary to reflect practical technology on the scope through active research activities by developing the system of fireproof exterior wall structures capable of preventing fire spreads such as steel curtain wall method using steel etc., evacuation technology and smoke control technology. Therefore, fire safety alternatives for high rise buildings should be secured as described.

This study has been conducted by the relevant study to "Development of smoke control/evacuation schemes and over 3-hour fire rated structural members in case of fire in large-space buildings" project, a major project of KICT. 
$1^{\text {st }}$ International Seminar for Fire Safety of Facades, Paris (France), 2013

\section{References}

[1] National Emergency Management Agency: Fire Statistic History (2007, 2008 and 2009) and Statistics Data of National Emergency Management Agency (http://www.nema.go.kr)

[2] Yoo, Yong-Ho, Kim, Heung-Youl, Min, Se-Hong etc.: Technology Development on Vertical fire spreading prevention of exterior material of the buildings, Interim report on Fire Fighting Safety Technology Development Project for the Next Generation, 2010

[3] V. Babrauskas, S.J. Grayson: Heat Release in Fires, Elsevier, 1992

[4] ISO 13785-2 : Reaction-to-Fire tests for facades-Part 2 Large-scale test, 2002 